\title{
Haemostatic Potential of Medicinal Plants and Their Phytochemicals
}

\author{
Mamta Baunthiyal $^{1 *} \cdot$ Preeti Semwal $^{1} \cdot$ Sushmita Dwivedi $^{1}$ \\ ${ }^{1}$ Department of Biotechnology, G. B. Pant Institute of Engineering and Technology, Ghurdauri, Pauri, Garhwal, \\ Uttarakhand, India
}

*Corresponding Author Email id: mamtabaunthiyal@yahoo.co.in

Received: 15.02.2021; Revised: 03.03.2021; Accepted: 31.03.2021

(C)Society for Himalayan Action Research and Development

\begin{abstract}
Haemorrhage associated with traumatic injury is responsible for over $35 \%$ of pre-hospital deaths and over $40 \%$ of deaths within the first 24 hours. Some important pharmacological aspects of plants such as haemostatic potential remain underexplored due to lack of scientific validation for the medical use of plant extracts/active compounds in bleeding control. In this study, an ethnobotanical survey of medicinal plants, which are used to stop bleeding, was done. Information was gathered from local herbalists, elderly people, literature search through various books and previously reported research papers in scientific databases (Pubmed, Science Direct, Scopus, Chem Spider, PubChem). Information about plants used to treat bleeding, plant parts used, mode of preparation, possible compounds and mechanism of action and dosage was collected and recorded. The collected information revealed 92 medicinal plants belonging to 59 families which are used against bleeding. Members of the Asteraceae family (12\%) were the most prominent, followed by Moraceae (6\%), Poaceae (5\%) and Euphorbiaceae (4\%). Leaves and underground plant parts were reported to be the most commonly used plant parts. The most prominent methods of herbal administration used were intravenous and as an ointment on the body surface. These plant extracts can be used efficiently and in a managed proportion to develop an effective remedy for bleeding/haemorrhages.
\end{abstract}

Keywords: Medicinal plants $\bullet$ Haemorrhage $\bullet$ Asteraceae $\bullet$ Natural coagulants

\section{Introduction}

Haemorrhage: Cuts and wounds are inescapable in our life. But in case of excessive/ severe bleeding (haemorrhage) at the site of injury, wounds can be life-threatening. The severity of the injury is commonly associated with the degree of overall blood loss.Low blood pressure due to blood loss can lead to immediate complications, including the multiple organ failure and lifethreatening infections (Heckbert et al., 1998). After a traumatic injury, haemorrhage is responsible for over $35 \%$ of pre-hospital deaths and over $40 \%$ of deaths within the first 24 hours (Kauvar et al., 2006). Obstetric haemorrhage is the world's leading cause of maternal mortality, responsible for an estimated 127000 deaths annually (Kumar, 2016). Postpartum haemorrhage $(\mathrm{PPH})$ is the most common type of obstetric haemorrhage and accounts for the majority of the
14 million cases that occur each year (WHO, 2007).

Prevention of haemorrhages and bleeding complications is possible by using agents that initiate or fasten the haemostasis process in the body. Haemostatic agents (Aprotinin, Epsilonaminocaproic acid and Tranexamic acid, desmopressin, recombinant coagulation protein) improve haemostasis by stimulating fibrin formation, or inhibiting fibrinolysis.Unfortunately, the limited number of available drugs, the adverse effect associated and strict selection criteria for being accepted for a drug (undesirable effect of drugs on patients suffering from myocardial infarction), result in a small number of patients being eligible. Hence, there is a need for an alternative treatment that is faster, cheaper, safer, and effective.Treating haemorrhage / bleeding using medicinal plants is a common practice in many parts of the world. There are several herbs 
that have been prescribed by Ayurvedic medicineto treat haemorrhage, and some of them have been used since ancient times.

Haemostasis: Haemostasis, a natural process to stop bleeding after injury, is critical for survival. Haemostasis involves a complex cascade of reactions which initiates at the site of injury as a counter response as soon as an injury is confronted by the body.

Fibrinolysis: After clotting and coagulation are complete (generally between 3-6 minutes after injury) the unneeded clot is dissolved and removed by a process called fibrinolysis.

\section{Plants as a factory of natural medicines}

Plant extracts have been a vital element of ethno medicine since ancient times (Petrovska, 2012). Knowledge about medicinal plants is documented in old written manuscripts and also orally transferred. In India, Ayurveda is a rich Hindu heritage that documents medicinal plants and their potential uses, including plants that show haemostatic activity. Plants still form a base of medicines for various diseases. Allopathic medicine can cure a wide range of diseases; however, the escalating prices and side effects (toxicity) are forcing people to incline towards the herbal medicine. The Plant-based medicines are notonly cheap but are also safehaving no side effects when used in managed proportion.

Plants are being examined and evaluated scientifically for their medicinal potency. Most of the plant extracts have been evaluated by researchers for their anti-inflammatory, antidiarrheal, analgesic, anti-cancerous, antimicrobial, antidiabetic and antihemorrhagic activities but some other important pharmacological aspects such as haemostatic potential remain underexplored. There is a need for continued exploration and examination of plants for the presence of more potent coagulants, for analysing toxicity and optimum dose to develop an efficacious remedy for bleeding and with faster action.

\section{Ethno-Pharmacological Data Collection}

All the information for this review was obtained from different books, the electronic database such as Google Scholar, PubMed, local herbalists, elderly people and from a range of publications reporting and validating the haemostatic potential of plants.

\section{Plants with Haemostatic Potential}

Details of 92 plants were obtained, which are known to exhibit haemostatic activity. Asteraceae is the most common plant family among these plants (12\%). Parameters such as prothrombin time (PT), activated partial thromboplastin time (APTT), clotting time (CT), bleeding time (BT) and time of recalcification of plasma were used by researchers to evaluate the potential of these plants and validate their use as a remedy for bleeding (Table 1).

Table 1 Plants exhibiting haemostatic activity with the possible coagulants present in them

\begin{tabular}{|c|c|c|c|c|c|}
\hline $\begin{array}{l}\text { S. } \\
\text { No. }\end{array}$ & Plant & Family & Coagulant & Parts used & References \\
\hline 1. & Acacia Arabica L. & Fabaceae & Alkaloid & Gum & Raoof et al., 2013 \\
\hline 2. & Acalypha australis L. & Euphorbiaceae & Tannin & Whole plant & $\mathrm{Li}, 2002$ \\
\hline 3. & Ageratum conyzoides $\mathrm{L}$. & Asteraceae & Tannin & Leaf & Bamidele et al., 2010 \\
\hline 4. & Agrimonia eupatoria L. & Rosaceae & Tannin & Whole plant & $\mathrm{Li}, 2002$ \\
\hline 5. & Anacardium occidentale $\mathrm{L}$. & Anacardiaceae & $\begin{array}{l}\text { Tannin, } \\
\text { alkaloid }\end{array}$ & Stem bark & Arokoyo et al., 2015 \\
\hline 6. & Annona senegalensis Pers. & Annonaceae & Tannin & Leaf & $\begin{array}{l}\text { Dandjesso et al., } \\
2012\end{array}$ \\
\hline 7. & $\begin{array}{l}\text { Ardisia japonica (Hornst.) } \\
\text { Blume }\end{array}$ & Primulaceae & Alkaloid & Whole plant & $\mathrm{Li}, 2002$ \\
\hline 8. & Artemisia аппиа L. & Asteraceae & Not reported & Whole plant & Wang et al., 2009 \\
\hline 9. & 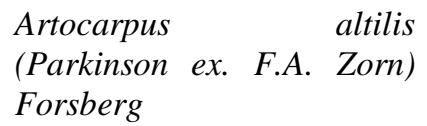 & Moraceae & Protease & Latex & Singh et al., 2015 \\
\hline 10. & AspidiumfalcatumSw. & Aspidiaceae & Tannin & Whole plant & $\mathrm{Li}, 2002$ \\
\hline
\end{tabular}




\begin{tabular}{|c|c|c|c|c|c|}
\hline 11. & Biota chinensis Hort. & Cupressaceae & Not reported & Twig & $\mathrm{Li}, 2002$ \\
\hline 12. & Biota orientalis L. & Cupressaceae & Not reported & Twig & $\mathrm{Li}, 2002$ \\
\hline 13. & Bletilla hyacinthine R.Br. & Orchidaceae & Not reported & Tuber & $\mathrm{Li}, 2002$ \\
\hline 14. & Callicarpa macrophylla L. & Verbenaceae & $\begin{array}{l}\text { Tannin, } \\
\text { flavone }\end{array}$ & Leaf,root & $\mathrm{Li}, 2002$ \\
\hline 15. & $\begin{array}{l}\text { Capsella bursa-pastoris (L.) } \\
\text { Medicus }\end{array}$ & Brassicaceae & Alkaloid & Whole plant & $\mathrm{Li}, 2002$ \\
\hline 16. & Carduus acaulis Thunb. & Asteraceae & Not reported & Leaf, stem & Li, 2002 \\
\hline 17. & Carduus crispus L. & Asteraceae & Not reported & Leaf, stem & $\mathrm{Li}, 2002$ \\
\hline 18. & Caraduus japonicas Franch. & Asteraceae & Not reported & Leaf,stem & $\mathrm{Li}, 2002$ \\
\hline 19. & Carica papaya $\mathrm{L}$ & Caricaceae & $\begin{array}{l}\text { Tannin, } \\
\text { alkaloid }\end{array}$ & Leaf & Patil et al., 2013 \\
\hline 20. & Cassia absusLinn & Caesalpiniaceae & Not reported & Seed & Varier, 2010 \\
\hline 21. & Cassytha filiformis & Lauraceae & $\begin{array}{l}\text { Alkaloid, } \\
\text { tannin }\end{array}$ & Aerial part & $\begin{array}{l}\text { Dandjesso et al., } \\
2012\end{array}$ \\
\hline 22. & Cephalanoplossegtum & Asteraceae & Alkaloid & Aerial part & $\mathrm{Li}, 2002$ \\
\hline 23. & Chromolaena odorata & Asteraceae & Not reported & Leaf & Pandith et al., 2012 \\
\hline 24. & Cissampelos mucronate & $\begin{array}{l}\text { Menispermacea } \\
\mathrm{e}\end{array}$ & $\begin{array}{l}\text { Alkaloid, } \\
\text { tannin }\end{array}$ & Aerial part & $\begin{array}{l}\text { Dandjesso et al., } \\
2012\end{array}$ \\
\hline 25. & Cissus quadrangularis Linn. & Vitaceae & Not reported & Whole plant & Varier, 2010 \\
\hline 26. & Citrus medica Linn. & Rutaceae & Not reported & Fruit & Varier, 2010 \\
\hline 27. & $\begin{array}{l}\text { ClinopodiumChinense(Bent } \\
\text { h.) }\end{array}$ & Lamiaceae & Not reported & Whole plant & $\mathrm{Li}, 2002$ \\
\hline 28. & CornusfloridaL. & Cornaceae & Tannin & - & $\mathrm{Li}, 2002$ \\
\hline 29. & Cotyledon fimbriatum Turcz & Crassulaceae & Not reported & Whole plant & $\mathrm{Li}, 2002$ \\
\hline 30. & Curcuma longa Linn. & Zingiberaceae & Not reported & Rhizome & Varier, 2010 \\
\hline 31. & $\begin{array}{l}\text { Cynodondactylon(Linn.) } \\
\text { Pers. }\end{array}$ & Poaceae & Not reported & Whole plant & Varier, 2010 \\
\hline 32. & DaemonoropsdracoBlume. & Arecaceae & Not reported & Fruits & Li, 2002 \\
\hline 33. & DioscoreacirrhosaL. & Dioscoreaceae & Tannin & Tuber & Li, 2002 \\
\hline 34. & DioscoreahispidaDennst. & Dioscoreaceae & Tannin & Tuber & $\mathrm{Li}, 2002$ \\
\hline 35. & Dipsacus asper & Caprifoliaceae & $\begin{array}{l}\text { Dipsacus } \\
\text { saponin C }\end{array}$ & Whole plant & Song et al.,2012 \\
\hline 36. & Eclipta alba Hassk. & Asteraceae & Alkaloid & Aerial part & Li, 2002 \\
\hline 37. & EcliptaerectaL. & Asteraceae & $\begin{array}{l}\text { Tannin, } \\
\text { nicotine }\end{array}$ & Aerial Part & Li, 2002 \\
\hline 38. & Ficus hispidaLinn.f. & Moraceae & Not reported & Fruit & Varier, 2010 \\
\hline 39. & Ficus microcarpaLinn.f. & Moraceae & Not reported & Bark, leaf & Varier, 2010 \\
\hline 40. & Ficus palmataForsk. & Moraceae & Not reported & Latex & Bhatt et al.,2010 \\
\hline 41. & Ficus religiosa Linn. & Moraceae & Not reported & Latex & Varier, 2010 \\
\hline 42. & $\begin{array}{l}\text { Gardenia } \\
\operatorname{augusta}(\mathrm{L} .) \text { Merrill. }\end{array}$ & Rubiaceae & Not reported & Fruit,flower,bark & $\mathrm{Li}, 2002$ \\
\hline 43. & Gardenia jasminoidesEllis & Rubiaceae & Not reported & $\begin{array}{l}\text { Fruit, } \\
\text { flower,bark }\end{array}$ & $\mathrm{Li}, 2002$ \\
\hline 44. & Hippophaèrhamnoides L. & Elaeagnaceae & $\begin{array}{l}\text { Not } \\
\text { reported }\end{array}$ & Fruit & Bal et al., 2011 \\
\hline 45. & Houttuynia cordata Thunb. & Saururaceae & Not reported & Aerial part & Li, 2002 \\
\hline 46. & Imperataarundinacea Cyrill. & Poaceae & Not reported & Root & Li, 2002 \\
\hline 47. & $\begin{array}{l}\text { Imperata } \quad \text { cylindrica } \\
\text { L.Beauv. }\end{array}$ & Poaceae & Not reported & Root & $\mathrm{Li}, 2002$ \\
\hline 48. & $\begin{array}{l}\text { Iris lacteal Pall. subsp. } \\
\text { chinensis(Fisch.)Kitag }\end{array}$ & Iridaceae & Not reported & $\begin{array}{l}\text { Seed,flower, } \\
\text { leaf,root }\end{array}$ & Li, 2002 \\
\hline 49. & Jatropha curcasL. & Euphorbiaceae & $\begin{array}{l}\text { Alkaloid, } \\
\text { tannin }\end{array}$ & Leaf & Azikiwe et al., 2014 \\
\hline 50. & Jatropha gossypifolia L. & Euphorbiaceae & $\begin{array}{l}\text { Alkaloid, } \\
\text { tannins }\end{array}$ & Stem latex & Odula et al., 2005 \\
\hline 51. & Jatropha multifida & Euphorbiaceae & Not reported & Plant sap & Dougnon et al., 2012 \\
\hline 52. & $\begin{array}{l}\text { Loropetalumchinense(R.Br.) } \\
\text { D.Oliver }\end{array}$ & $\begin{array}{l}\text { Hamamelidacea } \\
\mathrm{e}\end{array}$ & Flavones & Whole plant & $\mathrm{Li}, 2002$ \\
\hline
\end{tabular}




\begin{tabular}{|c|c|c|c|c|c|}
\hline 53. & Luffa aegyptiaca Mill. & Cucurbitaceae & $\begin{array}{l}\text { Vitamin } \mathrm{A}, \\
\mathrm{B}, \mathrm{C}\end{array}$ & Fruit, fiber & $\mathrm{Li}, 2002$ \\
\hline 54. & Luffa cylindrical L.Roem. & Cucurbitaceae & Not reported & - & Li, 2002 \\
\hline 55. & Mentha asiatica & Lamiaceae & Not reported & Root & Eisenman, 2013 \\
\hline 56. & Musa sapientum & Musaceae & $\begin{array}{l}\text { Alkaloid, } \\
\text { tannin }\end{array}$ & Plant sap & Klotoé et al., 2012 \\
\hline 57. & NewbouldialaevisSeem. & Bignoniaceae & Tannin & Leaf & $\begin{array}{l}\text { Dandjesso et al., } \\
2012\end{array}$ \\
\hline 58. & Ophioglossumvulgatum L. & $\begin{array}{l}\text { Ophioglossacea } \\
\text { e }\end{array}$ & Not reported & Whole plant & Li, 2002. \\
\hline 59. & Polygonum bistorta L. & Polygonaceae & Not reported & Stem, root & Li, 2002 \\
\hline 60. & Psidium guajava $\mathrm{L}$. & Myrtaceae & Not reported & Leaf & Jadhav et al., 2013 \\
\hline 61. & Pyrola decorataH. Andres & Ericaceae & Not reported & Whole plant & $\mathrm{Li}, 2002$ \\
\hline 62. & Pyrola rotundifolia $\mathrm{L}$. & Ericaceae & Not reported & Whole plant & $\mathrm{Li}, 2002$ \\
\hline 63. & Quercus pubescens Willd. & Fagaceae & Not reported & Fruit & Jadhav et al., 2013 \\
\hline 64. & Rheum officinale Baill. & Polygonaceae & Not reported & Rhizome & $\mathrm{Li}, 2002$ \\
\hline 65. & $\begin{array}{l}\text { Rubia chinensis Regel } \\
\text { \&Maack }\end{array}$ & Rubiaceae & Not reported & Root & $\mathrm{Li}, 2002$ \\
\hline 66. & Rubia cordifolia Thumb. & Rubiaceae & Not reported & Root & Li, 2002 \\
\hline 67. & $\begin{array}{l}\text { Saccharum officinarum } \\
\text { Linn. }\end{array}$ & Poaceae & Not reported & Stem & Varier, 2010 \\
\hline 68. & Santalum album Linn & Santalaceae & Not reported & Heartwood & Varier, 2010 \\
\hline 69. & Sedum aizoon $\mathrm{L}$. & Crassulaceae & Not reported & Whole plant & $\mathrm{Li}, 2002$ \\
\hline 70. & Streblus asper Lour. & Moraceae & Not reported & Root & Varier, 2010 \\
\hline 71. & $\begin{array}{l}\text { Symplocoscochinchinensis( } \\
\text { Lour.) Moore ssp. } \\
\text { laurina(Retz.)Nooteboom }\end{array}$ & Symplocaceae & Not reported & Bark & Varier, 2010 \\
\hline 72. & $\begin{array}{l}\text { Syzygiumjanbos(Linn) } \\
\text { Alston }\end{array}$ & Myrtaceae & Not reported & Bark & Varier, 2010 \\
\hline 73. & $\begin{array}{l}\text { Tabernaemontanadivaricata } \\
\text { (L.) R. Br. ex. Roem. and } \\
\text { Schult. }\end{array}$ & Apocynaceae & Protease & Latex & Singh et al.,2015 \\
\hline 74. & Tagetes erectaL. & Asteraceae & Not reported & Leaf & Dasgupta et al., 2014 \\
\hline 75. & Tectona grandis Linn.f. & Verbenaceae & Not reported & Leaf & Varier, 2010 \\
\hline 76. & $\begin{array}{l}\text { Terminalia } \\
\text { bellirica(Gaertn.) Roxb. }\end{array}$ & Combretaceae & Not reported & Fruit & Varier, 2010 \\
\hline 77. & Terminalia chebula Retz. & Combretaceae & Not reported & Fruit & Jadhav et al., 2013 \\
\hline 78. & $\begin{array}{l}\text { Thespesia } \\
\text { populnea(Linn)Soland ex } \\
\text { Correa }\end{array}$ & Malvaceae & Not reported & Whole plant & Varier ,2010 \\
\hline 79. & $\begin{array}{l}\text { Thevetia peruviana (Pers.) } \\
\text { K. Schum. }\end{array}$ & Apocynaceae & Not reported & Latex & Jadhav et al., 2013 \\
\hline 80. & Thymus vulgaris L. & Lamiaceae & Alkaloid & Leaf & Raoof et al., 2013 \\
\hline 81. & $\begin{array}{l}\text { TrachycarpuswagnerianusB } \\
\text { eccari }\end{array}$ & Arecaceae & Tannin & Seed & Li, 2002 \\
\hline 82. & $\begin{array}{l}\text { Trapa } \\
\text { natansLinn.var.bispinosa } \\
\text { (Roxb.) Makino }\end{array}$ & Trapaceae & Not reported & Fruit & Varier, 2010 \\
\hline 83. & Tribulus terrestrisLinn. & Zygophyllaceae & Not reported & Seed & Varier, 2010 \\
\hline 84. & Tridax procumbens Linn & Asteraceae & Not reported & Leaf & $\begin{array}{l}\text { Kale et al., 2008, } \\
\text { Trivedi, } 2009\end{array}$ \\
\hline 85. & $\begin{array}{l}\text { Vetiveriazizanioides(linn.) } \\
\text { Nash }\end{array}$ & Poaceae & Not reported & Root & Varier, 2010 \\
\hline
\end{tabular}




\begin{tabular}{|c|c|c|c|c|c|}
\hline 86. & $\begin{array}{lcr}\text { Vigna } & \text { radiata } & \text { (Linn) } \\
\text { Wilczek } & \text { var. } & \text { sublobata } \\
\text { (Roxb.) Verdc. } & \end{array}$ & Fabaceae & Not reported & Root & Varier, 2010 \\
\hline 87. & Vitex negundo Linn. & Verbenaceae & Not reported & Flower & Varier, 2010 \\
\hline 88. & Vitis vinifera Linn. & Vitaceae & Not reported & Fruit & Varier, 2010 \\
\hline 89. & $\begin{array}{l}\text { Woodfordia fruticose (Linn) } \\
\text { Kurz }\end{array}$ & Lythraceae & Not reported & Flower & Varier, 2010 \\
\hline 90. & $\begin{array}{l}\text { Zanthoxylum rhetsa(Roxb.) } \\
\text { DC. }\end{array}$ & Rutaceae & Not reported & Fruit & Jadhav et al., 2013 \\
\hline 91. & Zingiber officinale Roscoe & Zingiberaceae & Alkaloid & Rhizome & Jadhav et al., 2013 \\
\hline 92. & Ziziphus mauritianaLam. & Rhamnaceae & Not reported & Fruit & Varier, 2010 \\
\hline
\end{tabular}

As it is evident from the Table 1, Li (2002) and Varier (2010) documented most of the plants exhibiting haemostatic activity. But there is no valid in vitro and in vivo scientific study that evaluates their haemostatic activity.

\section{Studies on the haemostatic activity of plant extracts \\ a. In vitro:}

Odula et al. (2005) studied the coagulating and anti-coagulating activity of Jatropha gossypifoliaand found that latex from the stem of plant reduces blood clotting time. This procoagulant activity was assumed as a result of precipitation of clotting factors. The activity was evaluated on the basis of bleeding Time (BT) and (clotting time) CT. But active compounds and proper dosage were unidentified. Kale et al. (2008) reported haemostatic activity of the ethanolic extract of the fresh juice of leaves of Tridaxprocumbens. The activity was evaluated by determining CT. In the succeeding year, Wang et al. (2011) and Edemeka and Ogwu, (2009) screened the fraction of Artemisia annua L. and Ocimumgratissimumrespectively in vitro by plasma recalcification time. The haemostatic active extracts of $A$. апnua plants shortened the clotting time. Aqueous and methanol extract of $O$. gratissimum significantly shortened the APTT of normal and factor VII-deficient plasma samples. Its coagulating constituents were unidentified.

Dougnon et al. (2012)reported that theaddition of the sap of Musa sapientum in the whole blood induced a reduction of CT. The effect was not dose-dependent. It's mechanism of action was explained by vasoconstriction and cell aggregation (mediated by tannin). Phytochemical analysis revealed the presence of alkaloids, tannins, coumarins, reducing compounds, anthocyanins and leuco-anthocyanins. M.sapientumis very common in the South - Benin (West Africa) as a treatment of bleeding. This plant is also used in India and Brazil for haemostasis. Phytochemistry and in vitro haemostatic properties of some medicinal plants sold as anti-hemorrhagic in Benin were studied by Dandjesso et al. (2012). Annona senegalensis (Leaves), Newbouldialaevis (Leaves), Cassythafiliformis(Aerial part), Cissampelosmucronata (Aerial part) are the four species of medicinal plants commonly sold by herbalists in South Benin for the treatment of bleeding. Hydro alcoholic extracts of these plants reduced plasma re-calcification time and validated their coagulant properties. The coagulation activity is related to the presence of tannin in these plant extracts. The phytochemical study of these plants revealed that $C$. mucronata contains alkaloids and tannins; A. senegalensis contains tannins, mucilages and reducing compounds; $C$. filiformis contains alkaloids, tannins and $N$. laevis contains tannins, triterpenoids, mucilages and reducing compounds.

Jadhav et al. (2013) screened ten Indian herbs for haemostatic activity in vitro. Of the ten plants evaluated, aqueous extracts of Quercus pubescens, Thevetia peruviana proved to have significant haemostatic activity, whereas alcoholic extracts of Zingiber officinale, Zanthoxylumrhetsaand petroleum ether extracts of Psidumguajava, 
Terminalia chebula, Zanthoxylumrhetsa confirmed the haemostatic activity.

Blood coagulation activity of the marigold leaf extract was reported by Dasgupta et al. (2014). Activity was evaluated on the basis of PT. Leaf extract showed very good blood coagulation properties in the microlitre range. However, the active compounds were not identified. In the same year, Badgujar (2014) evaluated the haemostatic activity of latex from three plants belonging Euphorbiaceae family. These were Euphorbia nivulia Buch. -Ham., Pedilanthustithymaloides(L.) Poit and Synadeniumgrantii Hook F. The activity was assessed by the determination of bleeding/clotting time test of the fresh experimentally-induced wound in mice. In vitro studies were also done on the blood sample of human, goat, buffalo and ox by detecting the procoagulant activity of latex of these plants. E. nivulia latex showed the best blood clotting activity followed by $P$. tithymaloides and $S$. grantii. The haemostatic activity was reported due to the presence of the protease in the latex. In another study, Singh et al. (2015) estimated the proteolytic activity of crude extract of plants Tabernaemontanadivaricata (L.) R. Br. ex. Roem. and Schult. and Artocarpusaltilis (Parkinson ex. F.A. Zorn) Forsberg and found that crude enzymes from both plants exhibited coagulant activity on human platelet poor plasma. A significant reduction in clotting time was exhibited by $T$. divaricata compared to $A$. altilis.Ohkuraet al. (2015) screened for the haemostatic activity of popular Chinese medicinal herbs and concluded that extracts of Alpinia Rhizome, Areca, Artemisia Leaf, Cassia Bark, Danshen Root, Ephedra Herb, Epimedium Herb, Forsythia Fruit, Great Burdock Achene, Moutan Bark, Perilla Herb, Red Paeony Root, Schizonepeta Spike, Senticosus Rhizome, Sweet Annie, Uncaria Thorn and Zanthoxylum Peel shorten the coagulation time of blood.

b. In vivo: Geranium (Pelargonium zonale) has been traditionally used as a local haemostatic medicine in some Andean region. Paez and Hernandez (2003) studied its haemostatic effect using bleeding rat model and found that leaf juice of $P$. zonale shortened the bleeding time by $50 \%$ as compared to control group. They also proved that haemostatic agent gelatin sponge showed the similar effect as geranium juice. Ankaferd Blood Stopper®, which has been approved in the management of external haemorrhage and dental surgery bleedings in Turkey, comprises a standardized mixture of plants viz. Thymus vulgaris, Glycyrrhiza glabra, Vitis vinifera, Alpinia officinarum and Urtica dioica.Cipilet al. (2009) reported in vivo haemostatic effect of the medicinal plant extract Ankaferd Blood Stopper® in rats pretreated with warfarin.Bamidele et al. (2010) reported haemostatic activity of methanolic leaf extract of Ageratum conyzoides by determining BT, PT, CT in albino rats and the activity was due to the possible interaction of extract with both intrinsic and extrinsic pathways. Bal et al. (2011) described that fruits of Hippophaerhamnoides L. have haemostatic effects.

Dougnon et al. (2012)studied the haemostatic potential of the sap of Jatropha multifida in wistar rats and found a significant reduction in bleeding time. The phytochemical screening showed the presence of tannins, flavonoids, saponins, leucoanthocyanes, mucilage and reducing compounds in the sap of $J$. multifida. The haemostatic power of the sap was explained by the strong presence of tannins and flavonoids. In vivo and in vitro haemostatic activity of Chromolaena odorata leaf extract was investigated by Pandith et al. (2012). In vitro haemostatic mechanisms were tested using platelet aggregation and blood coagulation tests in sheep plasma. Ethanol extract from the dried leaves decreased the bleeding time in vivo. Song et al. (2012) discovered that Dipsacus asper, known to have analgesic and antiinflammatory effects, potently induced procoagulant activities in platelets. Dipsacus saponin C (DSC) was identified as a key active ingredient in plant induced procoagulant activities. Extracts of Zingiber officinale Roscoe, Thymus vulgaris $\mathrm{L}$. and Acacia arabica $\mathrm{L}$. was found to contain a higher percentage of alkaloids and was effective in coagulation as it decreased both BT and $\mathrm{CT}$ and increased platelets, $\mathrm{RBC}, \mathrm{WBC}$ and 
calcium count (Raoof et al., 2013). The study was done on lab mice. Carica papaya leaf extract was found to increase the platelet count and also to decrease the clotting time in thrombocytopenic rats as reported by Patilet al. (2013). Aqueous extract of $C$. papaya leaves at a concentration of $400 \mathrm{mg} / \mathrm{kg}$ and $800 \mathrm{mg} / \mathrm{kg}$ was given to cyclophosphamide-induced thrombocytopenic rats for a period of fifteen days. Blood was withdrawn at the various time intervals to determine the platelet count. Azikiweet al. (2014) carried out some in-vivo and in-vitro haemostatic studies of the leaf extracts of Jatropha curcas in rats and scientifically demonstrated its possible coagulant activity. The phytochemistry and acute toxicity testing were done. Acute toxicity level was $28.28 \mathrm{mg} / \mathrm{kg}$ (IP). Phytochemistry revealed the presence of alkaloids, resin, oils, saponins, flavonoids, tannins and glycosides. Blood clotting time was shortened by both aqueous and ethanolic extract. The possible mechanism of action of the extract was described by the enhancement of carboxylation of trans-carboxylic acid (glutamate) residue, mimicking that of vitamin $\mathrm{K}$ or aggregation of platelets. Recently, Arokoyoet al. (2015) reported that methanolic stem bark extract of Anacardium occidentale L. possesses haemostatic activity as it significantly decreased BT, PT, CT and APTT in the albino rat in a dosedependent manner and increased platelet count. The anti-hemorrhagic activity of the leaf extract of Sidacorymbosa was evaluated in Wistar albino rats by John-Africa and Aboh, 2015. The haemostatic activities of the extract were investigated using the tail bleeding time and amount of bleeding in rats. Phytochemical screening confirmed the presence of tannins, saponins, alkaloids, flavonoids, carbohydrates, terpenes and sterols.

\section{Plant-based coagulants and mechanism of action}

Various coagulants or coagulation inducing agent that are reported to be present in plant extracts are:

i. Concanavalin A and other legume lectins (phytohaemagglutinin): Concanavalin $\mathrm{A}$ is a lectin originally extracted from jack bean. It directly agglutinates erythrocytes irrespective of blood groups. Concanavalin A interacts with different receptors (made up of structures like sugars, glycoproteins, glycolipids), including blood group markers.

ii. Alkaloids: Alkaloids are a class of naturally occurring organic nitrogen-containing bases. They are found primarily in plants and fungus. Alkaloids are derived from various amino acids such as ornithine, lysine, phenylalanine etc. About 5,500 alkaloids are known and they comprise the largest single class of secondary plant substances (Raoof et al., 2013). Some well-known alkaloids are: Nicotine, caffeine, morphine, colchicine, ergots, strychnine, quinine, reserpine.

Ergonovine (from fungus Claviceps purpurea) is used to reduce uterine haemorrhage after childbirth.

\section{iii. Phenols:}

Tannins, also called Tannic acid, have been reported to accelerate blood clotting. Tannins are known as an astringent agent. Astringent activity favors vasoconstriction, which is the initial step in haemostasis (Dougnonet al., 2012). Phenolic compounds of high molecular weight, containing hydroxyls and other suitable groups, form effectively strong complexes with macromolecules like protein and precipitate proteins (Ashok and Upadhyaya, 2012). Tannins follow the same mechanism in coagulating blood. Tannins are known to precipitate the clotting factors, thus helping in haemostasis (Dougnon et al., 2012). Their phenolic hydroxyl groups form strong hydrogen bonds with the protein (Crozier et al., 2009) rendering insoluble proteins that increase blood viscosity and slow down the movement of red blood cells. Thus, facilitates their aggregation. Increased aggregation produced locally in each capillary will instantly interrupt blood flow (Mchedlishvili et al., 2002).

iv. Vitamins (A, B, C): They are reported to be involved in the early synthesis of collagen fibers (Kumarasamyrajaet al., 2012). Collagen is one of the major activators of the platelet response after injury. Collagen is the only matrix protein which supports both platelet adhesion and complete activation. When collagen becomes exposed to flowing blood, platelets rapidly adhere, spread, 
become activated and begin to form an aggregate (Farndale et al., 2004).

\section{Conclusion}

Nature has provided a large variety and number of plants which contain biologically active and important compounds that show impressive blood coagulating activity. This review is an attempt to explore the haemostatic activity of such plants through documented and undocumented resources. The main obstacle to the development of an effective medicine for bleeding from these plant extracts is the lack of knowledge about their in-vivo activity, mechanism of action, toxicity and possible coagulants (compounds). There is a need for continuous exploration and evaluation of plants for the presence of more potent coagulants, for analysing toxicity and optimum dose to develop an efficacious remedy for bleeding and with faster action. The plant list documented in this review may prove valuable in the trend of plant medicine development for bleeding / haemorrhages.

\section{Acknowledgment}

We thank local people and herbalists of Pauri Garhwal (Uttarakhand) for giving their valuable time for this study.

\section{References}

Arokoyo DS, Bamidele O, Babatunde LD, Adebisi O (2015). Hemostatic effect of methanolic stem bark extract of Anacardium occidentale $\mathrm{L}$. in male albino rats. $\mathrm{J}$ Med. Medic Sci., 6:58-65.

Ashok PK, Upadhyaya K (2012). Tannins are Astringent. J Pharma. Phytochem. 1:45-50.

Azikiwe CCA, Ifezulike CC, Amazu LU, Nwabali MO (2014). Hemostatic effect of Jatropha curcas (Linn) in rats. Drug Discovery. 8:16-20.

Badgujar SB (2014). Evaluation of hemostatic activity of latex from three Euphorbiaceae species.J Ethnopharmacol. 151:733-739.
Bal LM, Medab V, Naika SN, Satya S (2011). Sea buckthorn berries: A potential source of valuable nutrients for nutraceuticals and cosmoceuticals. FOOD RES INT. 44:17181727.

Bamidele O, Akinnuga AM, Anyakudo MMC, Ojo OA, Ojo GB, Olorunfemi,JO, Johnson OP (2010). Hemostatic effect of methanolic leaf extract of Ageratum conyzoides in albino rats.J. Med. Plants Res. 4:2075-2079.

Bhatt A, Baunthiyal M., Pandey, A., Dangwal, H, Singh, A.K., 2010. Ethnobotanical uses of plants for curing diseases and ailments by people of Pauri Garhwal. J. Mountain Res. 5:129-139.

Cipil HS, Kosar A, Kaya, A, Uz B, Haznedaroglu IC, Goker H, Ozdemir O, Koroglu M, Kirazil S, Firat HC (2009). In vivo hemostatic effect of the medicinal plant extract Ankaferd Blood Stopper in rats pretreated with warfarin. Clin Appl Thromb Hemost 15:270276.

Crozier A, Jaganath IB, Clifford MN, Dietary phenolics: chemistry, bioavailability and effects on health. Nat. Prod. Rep. 26:10011043.

Dandjesso C, Klotoé JR, Dougnon TV, Sègbo J, Atègbo JM, Gbaguidi F, Fah L, Fanou B, Loko F, Dramane K (2012). Phytochemistry and hemostatic properties of some medicinal plants sold as anti-hemorrhagic in Cotonou markets (Benin). Indian J Sci Technol. 5:3105-3109.

Dasgupta N, Ranjan S, Saleh MA Arabi Mohammed, Jadon PS, Melvin SS, Harris AD, Chakraborty AR, Ramalingama C (2014). Extraction based blood coagulation activity of marigold leaf: Acomparative study.Comp Clin Path. 23:1715-1718.

Dougnon TV, Klotoé JB, Sègbo J, Atègbo JM, Edorh,AP, Fernand G, Hounkpatin AS, Dandjesso C, Fah L, Fanou B, Dramane K, Loko F (2012). Evaluation of the phytochemical and hemostatic potential of Jatropha multifida sap.Afr. J. Pharm. Pharmacol. 6:1943-1948. 
Edemeka DBU, Ogwu AS (2009). Blood coagulation activities of leaf extracts of Ocimumgratissimum plant in man. J Herbs Spices Med Plants. 7:9-14.

Eisenman SW, Zaurov DE, Struwe L (2013). Medicinal Plants of Central Asia: Uzbekistan and Kyrgyzstan. Heidelberg Dordrecht London New York. Springer.

Farndale RW, Sixma JJ, Barnes MJ, de Groot PG (2004). The role of collagen in thrombosis and haemostasis. J ThrombHaemost. 2:56173.

Heckbert SR, Vedder NB, Hoffman W, Winn RK, Hudson LD, Jurkovich GJ, Copass MK, Harlan JM, Rice CL, Maier RV (1998). Outcome after hemorrhagic shock in trauma patients. J Trauma. 45:545-549.

Jadhav S., Kulkarni C, Salunkhe S, Deshpande A, Bhise S (2013). Screening of Indian herbs for hemostatic activity. $J$ drug delivTher. 3:8185.

John-Africa LB, Aboh M (2015). Evaluation of the Hemostatic Activities of Sidacorymbosa in Rats. Br J Pharm Res. 5:431-436.

Kale MA, Shahi SR, Somani VG, Shamkuwar PB, Dhake AS (2008). Hemostatic activity of the leaves of Tridaxprocumbens Linn. Int $J$ Green Pharm. 2:54-55.

Kauvar DS, Lefering R, Wade CE (2006). Impact of hemorrhage on trauma outcome: an overview of epidemiology, clinical presentations, and therapeutic considerations. J Trauma. 60: S3-11.

Kumar N (2016). Postpartum hemorrhage; a major killer of woman: review of current scenario. ObstetGynecol Int J. 4(4):00116.

Kumarasamyraja D, Jeganathan NS, Manavalan R (2012). A review on medicinal plants with potential wound healing activity. Int $J$ Pharma Sci. 2:105-111.

Li TSC (2002). Chinese and Related North American Herbs: Phytopharmacology and Therapeutic values. Boca Raton London New York Washington D.C.:CRC Press.

McHedlishvili G, Varazashvili M, Gobejishvili L (2002). Local RBC aggregation disturbing blood fluidity and causing statis in microvessels. Clin HemorheolMicrocirc. 26:99-106.

Oduola T, Adeosun GO, Oduola TA, Avwioro GO, Oyeniyi AM (2005). Mechanism of action of Jatropha gossypifolia stem latex as a hemostatic agent. Eur J Gen Med. 2:140143.

Ohkura N, Yokouchi H, Mimura M, Nakamura R, Atsumi GI (2015). Screening for hemostatic activities of popular Chinese medicinal herbs in vitro. J intercultethnopharmacol. 4:19-23.

Paez X, Hernandez L (2003). Topical hemostatic effect of a common ornamental plant, the geraniaceae Pelargonium zonale. J CLIN PHARMACOL. 43:291-295.

Pandith H, Thongpraditchote S, Wongkrajang Y, Gritsanapan W (2012). In vivo and in vitro hemostatic activity of Chromolaenaodorata leaf extract. Pharm Biol. 50:1073-1077.

Patil S, Shetty S, Bhide R, Narayanan S (2013). Evaluation of platelet augmentation activity of Carica papaya leaf aqueous extract in rats. J PharmacognPhytochem. 1:57-60.

Petrovska BB (2012). Historical review of medicinal plants'usage. Pharmacogn Rev. 6:1-5.

Raoof AW, Zahraa Abdul-Elah Al-Naqqash, Abdul-Latif M jawad, Salah M Mushan( 2013). Evaluation of the activity of crude alkaloids extracts of Zingiber officinale Roscoe, Thymus vulgaris L. And Acacia Arabica L. as coagulant agent in lab mice. $J$ Biomed Biotechnol. 1:11-16.

Singh MK, Usha R, Hithayshree KR, Bindhu OS (2015). Hemostatic potential of latex proteases from Tabernaemontanadivaricata (L.) R. Br. ex. Roem. and Schult. and Artocarpusaltilis (Parkinson ex. F.A. Zorn) Forsberg. J Thromb Thrombolysis. 39:43-49.

Song JS, Lim KM, Kang S, Noh JY, Kim K, Bae ON, Chung JH ( 2012). Procoagulant and prothrombotic effects of the herbal medicine, Dipsacus asper and its active ingredient, dipsacus saponin $\mathrm{C}$, on human platelets. $J$ ThrombHaemost. 10:895-906. 
J. Mountain Res. P-ISSN: 0974-3030, E-ISSN: 2582-5011

Trivedi PC (2009). Medicinal Plants Utilization and Conservation. 2nd ed. Jaipur, India: Aaviskar Publishers

Varier PS (2010). IndianMedicinal Plants; $a$ compendium of 500 species. Volume 2,3,4-5. Kottakal: Orient Longman, Universities Press.

Wang B, Sui J, Yu Z, Zhu L (2011). Screening the hemostatic active fraction of Artemisia annua L. in-vitro. IranJ Pharm Res. 10:57-62

******* 